\title{
MATHEMATICS AND EFFICIENCY IN SECONDARY SCHOOL
} WORK -A REPLY.

\author{
By William Asker, \\ University of Washington, Seattle.
}

The March, 1916, issue of this Journal contains an article under the above heading, by Prof. Robert E. Moritz of the University of Washington; in which he makes a plea for giving mathematics a large place in secondary instruction. As this problem is a very important one, it deserves to be treated from different points of view, and-I am taking the liberty of trying to show the one-sidedness of Dr. Moritz's argument. I do this not as a mere student of educational theories, but as a teacher of secondary school mathematics.

The gist of the article by Dr. Moritz is contained in the following passage: "We are now in a position to understand why the study of mathematics must necessarily occupy a large place in secondary instruction. It is not because the theorems of geometry or the rules of algebra as such are of any great value to the high school graduate, though it will be admitted that they are indispensable to every scientific pursuit and to countless occupations and professions. The mere knowledge of the Pythagorean triangle relation or of the binomial theorem is probably of less immediate value to the average graduate than the knowledge of how to sharpen a knife or to sew on a button. But as an exercise. in fundamental thought processes, they are invaluable to every individual, no matter what his ultimate work in life may be."

In other words, Dr. Moritz bases his opinion upon the old and now generally abandoned doctrine of formal discipline. The arguments he offers consist of quotations from various writers on educational questions, from Plato to more recent ones. But Dr. Moritz has been rather unfortunate in selecting his authorities; and I will permit myself to give one or two citations from Plato and Locke, showing that they might as well be referred to by opponents of the doctrine of formal discipline if we select suitable passages. Says Plato: "All this is but the prelude to the actual strain that we have to learn. For you surely would not regard the skilled mathematician as a dialectician?" Assuredly not. $\mathrm{He}$ said: "I have hardly ever known a mathematician who was capable of reasoning." In his Conduct of the Understanding, Locke says: "We should always remember that the faculties

\footnotetext{
Jepublic (Jowett's transiation), p. 531.
} 
of our souls are improved and made useful to us, just after the same manner as our bodies are. Would you have a man write or paint, dance or fence, well, or perform any other manua! operation dextrously and with ease? Let him have ever so much vigor and activity, suppleness, and address naturally, yet nobody expects this from him unless he has been used to it, and has employed time and pains in fashioning and forming his hand, or outward parts, to these motions." And again, in Thoughts on Education: "I hear it is said that children should be employed in getting things by heart to exercise and improve their memories. I could wish this were said with as much authority or reason as it is with forwardness of assurance, and that this practice were established upon good observation more than old custom. For it is evident that strength of memory is owing to a happy constitution and not to any habitual improvement got by exercise. Is it not the same with the other faculties?"

But it is not my intention to base any argument upon quotations from authorities. I cite these passages only to demonstrate the value thereof. And yet this kind of argument is the only one employed by Dr. Moritz in his article. He quotes from his authorities passages that sustain his opinion, and he is ready with his conclusion that we should give a great deal of mathematics to all students in the secondary schools as an exercise of their reasoning power. His article would have been more valuable if he had presented the views of representatives of both sides, and weighed their arguments against each other.

The question of formal discipline has caused much dispute. While the older educational schools generally accept the doctrine of formal discipline, it has been attacked by modern writersmost vigorously, perhaps, by Thorndike, who holds that training the mind means the development of thousands of particular independent capacities. In a recent work, "Psychology of High School Subjects, Judd discusses the controversy, and finds the truth in the golden mean. No subject can claim for itself the monopoly of training the mind. The testing stone is the question: Is it taught in such a way as to give a generalized experience? No subject that becomes an end in itself does this. In other words, we must study from a philosophical point of view. What we must guard against is formalism in content as well as in mode of procedure. We must make the subject matter of vital interest, and the best way of doing so is by application. This means efficiency. 
Now, let us apply these principles to the teaching of mathematics. Nobody would deny that mathematics is of great practical value. It is needless to point out how one science after another adopts mathematical methods for solving its problems, to say nothing of its applications in technical and business life. But do we show this to our pupils in the high school? No, we rather let them understand that, although it would be much more useful for them to learn "how to sharpen a knife or to sew on a button," yet we insist on their studying mathematics as "an exercise in fundamental thought processes," and as "the most efficient agency for acquiring the power of quick attention and prolonged concentration of mind." We do not even suggest to them the relation between the two branches of mathematics, geometry and algebra, treating them as two alogether different subjects. While interest is a very important condition for learning with children, it is still more important with adolescents. And who will blame an adolescent whose whole soul and body are crying for action, for being unwilling to sit down on the school bench and study mathematics or any other subject that seems useless to him? We must take into account the nature of the youth if we want our school work to be efficient. If, instead of pure algebra or dry geometrical theorems, we gave problems related to the daily life or interests of the students, much would be gained. And this would offer an opportunity for acquiring generalized experience much more valuable for the training of the mind than the mathematics we generally give in high schools. I remember one case where I had to coach a boy in trigonometry, a subject that he thought of no value to him. I found out that his ambition was to become an artillery officer. I gave him a few problems relating to military science and that changed his mind. Then he saw that trigonometry was indispensable to his future profession, and in spite of his poor ability in mathematics he spared no effort in struggling through his course.

But even if much could be gained by modifying the topics to be studied and our methods of teaching mathematics, another question is if it is advisable to require every high school student to take this subject two or three semesters. Every experienced teacher knows that to many students mathematics is a very difficult subject. And if we admit that mathematics has no monopoly in "training the reasoning power," it seems as if it would be much more efficient to allow a greater freedom of electing subjects in the high school: No doubt, a student interested, for instance, in 
biology would profit much more by being permitted to devote a good deal of his time to this subject than by being compelled to study mathematics, which would be merely a drudgery to him.

I am not underestimating the great value of mathematics, as a high school subject, if properly taught, but we must guard against one-sidedness and formalism. Our schools can never reach maximum efficiency until we realize the importance of the maxim, Non scholae, sed vitae.

\title{
A METHOD OF COMPUTING CUBE ROOT.
}

\author{
By D. E. Davis, \\ Mt. Auburn, Ill.
}

I read Mrs. M. W. Arleigh's article on square root in the November, 1916, issue of School ScIENCE AND Mathematics, and at once thought of a similar method of finding a cube root of a number based on the common method of factoring the difference of two cubes.

Let $x$ and $y$ be any numbers.

$$
\begin{array}{rlrl}
x^{3}-y^{2} & =(x-y)\left(x^{2}+x y+y^{2}\right) . \\
y^{3} & =y^{3}+(x-y)\left(x^{2}+x y+y\right) \\
\text { When } x-y & =1, & x^{3} & =y^{3}+1\left(x^{2}+x y+y^{2}\right) . \\
\text { When } x-y & =2, & x^{3} & =y^{3}+2\left(x^{2}+x y+y^{2}\right) . \\
\text { When } x-y & =n, & x^{3} & =y^{3}+n\left(x^{2}+x y+y^{2}\right) .
\end{array}
$$$$
\text { When } x-y=2, \quad x^{3}=y^{3}+2\left(x^{2}+x y+y^{2}\right) \text {. }
$$

An example makes the method clear.

Find the cube root of $788,889.024$.

$\mathrm{By}$ inspection,

$x^{2}=92^{2}$

$x y=92 \times 90$

$y^{2}=90^{2}$

$x^{2}+x y+y^{2}$

$x-y=2$

$$
\begin{aligned}
& x^{2}=92.4 \\
& x y=92 \times 92.4 \\
& y^{2}=92^{2}
\end{aligned}
$$

$x^{2}+x y+y^{2}$

$x-y=.4$

Ans.

92.4 for

$$
\begin{aligned}
& 90^{8}=729,000 . \\
= & 8,464 \\
= & 8,280 \\
= & \frac{8,100}{24,844} \\
= & 2
\end{aligned}
$$

$$
\begin{aligned}
\overline{49,688} & =\frac{49,688}{92^{3}}=\frac{7778,688 .}{8,537}
\end{aligned}
$$

$8,537.76$

$8,500.8$

8,464

$25,502.56$

.4

$$
\begin{aligned}
\overline{10,201.024} & =\frac{10,201.024}{92.4^{2}}=\overline{788,889.024}
\end{aligned}
$$

The pupil should make out a table of cubes from one to ten, and from that he can find the first cube in the ordinary manner. The squares and products can be found by Mrs. Arleigh's metbod. 